\title{
THE LONG TERM CHANGES IN LIVER DNA AND TOTAL PROTEIN CONTENTS FOLLOWING LOW LEVEL SARIN EXPOSURE IN RATS
}

\author{
Jiř̌ Kassa ${ }^{1}$, František Skopec ${ }^{2}$, Josef Vachek ${ }^{1}$ \\ Purkyně Military Medical Academy, Hradec Králové: Department of Toxicology ${ }^{1}$; Charles University in Prague, Faculty \\ of Medicine in Hradec Králové: Radio-isotope Laboratory²
}

\begin{abstract}
Summary: 1 . The changes in contents of DNA and total protein in the liver of the rats exposed to low level sarin by inhalation at 3,6 and 12 months following the exposure were studied. The influence of sarin on the DNA and protein metabolism in liver was determinated by the measurements of incorporation of tritiated thymidine into DNA, the concentration of DNA and total protein. 2. Our results show that not only symptomatic level 3 but also asymptomatic levels 1 and 2 of sarin are able to significantly decrease the incorporation of radiolabelled thymidine without changing total concentrations of DNA as well as protein at three months following sarin exposure. On the other hand, the significant decrease in total contents of DNA and protein in liver without the changes in the incorporation of tritiated thymidine was determined in liver six months following sarin exposure. Practically no significant changes in the metabolism of DNA and protein were observed at 12 months following sarin exposure. 3. Thus, not only clinically manifested intoxication but also low-level, asymptomatic exposure to nerve agents such as sarin is able to influence the metabolism of nucleic acids as well as proteins even several months following the exposure.
\end{abstract}

Key words: Sarin; Low level inhalation exposure; DNA; Protein; Liver; Rat

\section{Introduction}

Sarin (isopropyl methylphosphonofluoridate) belongs to highly toxic organophosphorus compounds (OPs) that pose potential threats to both military and civilian population as evidenced in recent terorristic attacks in Japan (14). Its toxicity is believed to be due to irreversible inhibition of acetylcholinesterase (AChE, EC 3.1.1.7), the enzyme that normally catalyzes the hydrolysis of acetylcholine (ACh) at cholinergic synapses. The accumulation of ACh on cholinergic receptors causes the overstimulation of peripheral as well as central cholinergic nervous systems, clinically manifested as acute cholinergic crisis (12,21). Moreover, OPs have many other effects called as non-specific or non-cholinergic effects. They involve the activation of multiple neurotransmitter systems in the central nervous system, mutagenic, stressogenic, immunotoxic, hepatotoxic, membrane and hematotoxic effects (1).

Although the marked alteration of nucleic acid metabolism, including the genotoxic and carcinogenic effects, was mostly described for less toxic organophosphorus pesticides $(5,16,20)$, there are some results demonstrating the possible effects of highly toxic OPs on the metabolism of nucleic acids as well as proteins that can lead to the signs of genotoxicity. OP agent tabun was described as weakly acting mutagen using Salmonella spp. assays with S-9 and mouse lymphoma cells (19). A significant decrease in DNA synthesis in isolated hepatocytes following soman exposure in vitro was also shown (8).

The effects of OPs on nucleic acids and proteins have been demonstrated in vitro or in vivo following the exposure to relatively high dose of OP compounds. On the other hand, very little is known about the effects of low level exposure to OPs, especially to highly toxic OP agents, called nerve agents. At the same time, a few cases of exposure to low level nerve agents used as chemical warfare agents were observed in the nineties. Some military personnel serving in the Persian Gulf region during Operations Desert Storm/Shield might have been exposed to chemical warfare agents (probably sarin) in certain areas of the Gulf during the destruction of Iraqui ammunition bunkers after the war $(7,9)$. Therefore, the research is needed to determine how low level exposure to OPs, especially to nerve agents such as sarin, can cause the alteration of nucleic acid metabolism.

The aim of the study has been to find out whether a nerve agent sarin is able to produce the marked alteration of nucleic acid (DNA) metabolism and protein synthesis following single or repeated low level exposure in rats.

\section{Methods}

Male albino SPF rats weighing $180-220 \mathrm{~g}$ were purchased from Konárovice (Czech Republic). They were kept in 
an air-conditioned room and allowed access to standard food and water ad libitum. Food and water were sterilized before use. The rats were divided in groups of ten animals. Handling of the experimental animals were done under the supervision of the Animal Use and Care Committee of the Medical Faculty of Charles University and the Purkyně Military Medical Academy in Hradec Králové (Czech Republic).

Rats were exposed to low-level sarin (obtained from Zemianské Kostolany, Slovak Republic) in the inhalation chamber for 60 minutes. Low levels of sarin for the exposure were considered as those levels that result in minimal reduction of $\mathrm{AChE}$ with no observable clinical signs and no subjective symptoms. Three levels of sarin for the inhalation exposure were used as described:

- level 1 is an exposure that results in no clinical signs or symptoms and an erythrocyte AChE inhibition of $<20 \%$ $(0.8 \mu \mathrm{g} / \mathrm{l})$

- level 2 is an exposure that results in no clinical signs or symptoms but a moderate inhibition of erythrocyte AChE - about $20-30 \%$ (1.25 $\mu \mathrm{g} / \mathrm{l})$. This level was used for a single or repeated (three times per week) exposure

- level 3 is an exposure that results in mild clinical signs such as salivation and miosis without convulsions and an inhibition of erythrocyte AChE of 40-50\% (2.5 $\mu \mathrm{g} / \mathrm{l})$

Three, six or twelve months following the exposure to sarin, the rats were i.v. injected with radiolabelled (tritiated) thymidine $\left(25 \mu \mathrm{Ci}\left[{ }^{3} \mathrm{H}\right]\right.$ thymidine in the volume $0.5 \mathrm{ml}$ saline/100g b.w., UVVVR Prague, Czech Republic) and killed by exsanguination in total anaesthesia 60 minutes following tritiated thymidine administration. The liver was removed and the incorporation of tritiated thymidine into DNA in liver was determined according to Chmelař and Vodička (3). The activity of samples was measured using liquid scintilation counter LS 6000 LL (Beckman, USA) at dpm ${ }^{3} \mathrm{H} / \mathrm{g}$ of liver weight. Moreover, the concentration of liver DNA was determined at $600 \mathrm{~nm}$ using the spectrophotometer Apecol 20 (Carl Zeiss Jena, Germany) according to Burton (2) in modification of Chmelař and Vodička (3) at $\mu \mathrm{g}$ DNA/g of liver weight, the concentration of liver total protein was measured at $750 \mathrm{~nm}$ using the same spectrophotometer according to Lowry (11) in modification of Chromý and Vozníček (4) at $\mu \mathrm{g}$ total protein/g of liver weight. The experimental data are demonstrated as percentage of control values obtained from the control animals exposed to the pure air.

The statistical evaluation was made using the unpaired Student's t-test. The differences were considered to be significant when $\mathrm{p}<0.05$. Statistical evaluation was performed with relevant programs using an ADT 4500 computer.

\section{Results}

The absolute control values were between $13451 \pm 2090$ and $15478 \pm 4227 \mathrm{dpm}{ }^{3} \mathrm{H} / \mathrm{g}$ of liver weight (incorporation of tritiated thymidine), $2287 \pm 190$ and $2518 \pm 183 \mu \mathrm{g}$ DNA/g
Fig. 1: Changes in incorporation of tritiated thymidine (TdR) into DNA, DNA and total protein (TP) contents in the rat liver three months following the exposure to sarin. The data are represented as means \pm SD. Statistical significance: ${ }^{\mathrm{x}} \mathrm{p}<0.05$.

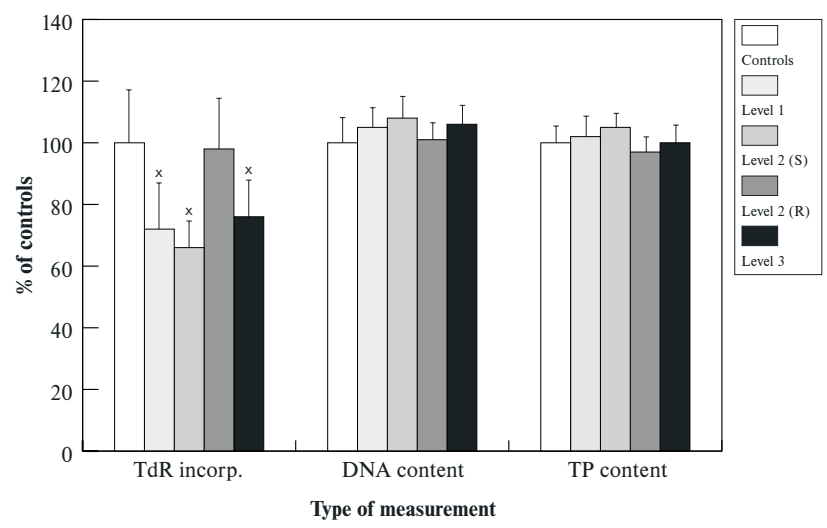

Fig. 2: Changes in incorporation of tritiated thymidine (TdR) into DNA, DNA and total protein (TP) contents in the rat liver six months following the exposure to sarin. For symbols - see Fig. 1.

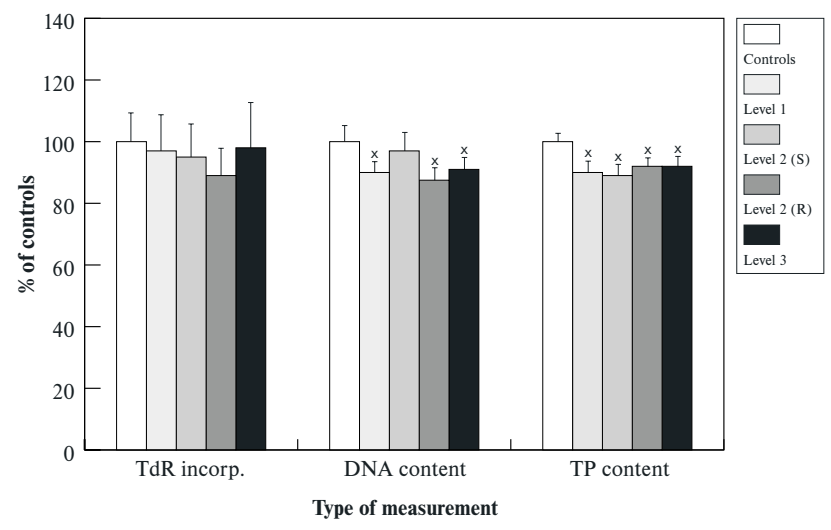

Fig. 3: Changes in incorporation of tritiated thymidine (TdR) into DNA, DNA and total protein (TP) contents in the rat liver twelve months following the exposure to sarin. For symbols - see Fig. 1.

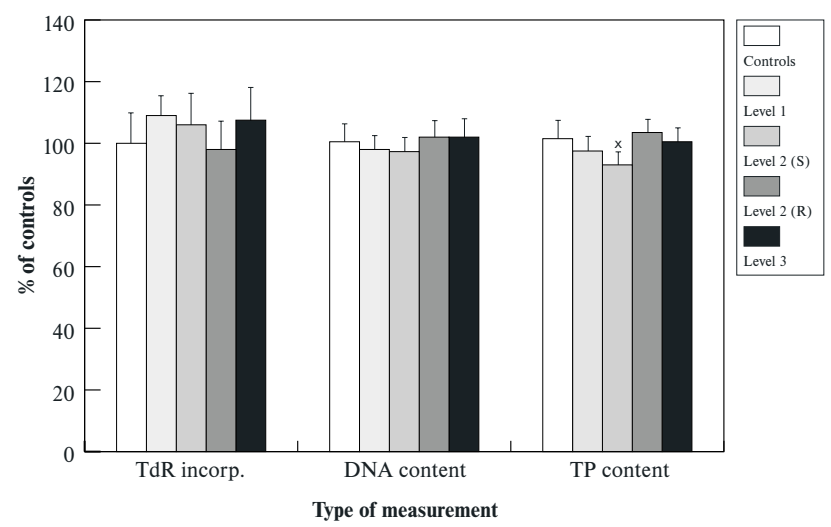


of liver weight (concentration of liver DNA) and 215702 \pm 19594 and $227467 \pm 8414 \mu \mathrm{g}$ total protein/g of liver weight (concentration of liver total protein). There were no significant differences between the control groups at 3, 6 and 12 months following the exposure to the pure air in the inhalation chamber.

The changes in a scheduled DNA synthesis de novo, representing DNA replication, measured by the incorporation of tritiated thymidine, and DNA as well as protein concentration in liver at three months following sarin exposure are shown in Fig. 1. Statistically significant $(p<0.05)$ decrease in the liver DNA synthesis following exposure of rats to sarin regardless of its level with the exception of repeated exposure of rats to sarin at level 2 was demonstrated. On the other hand, the content of DNA as well as total protein was not significantly influenced.

Different results were obtained at six months following the exposure to sarin as it is shown in Fig. 2. While DNA synthesis de novo, measured by the incorporation of tritiated thymidine, was not changed, a significant decrease in the content of DNA as well as total protein in liver following the exposure to sarin regadless of its level used was observed $(\mathrm{p}<0.05)$.

The influence of sarin exposure on the DNA and protein metabolism at twelve months following the exposure was neglectable as it is shown in Fig. 3. With the exception of the slight decrease in the content of total liver protein in rats exposed to sarin at level $2(\mathrm{p}<0.05)$, no significant changes in DNA and protein metabolism in liver were demonstrated.

No influence of sarin exposure on the body weight of rats was found. The values of body weight of rats were between $344 \mathrm{~g}$ and $353 \mathrm{~g}$ at 3 months following the exposure to sarin or the pure air, $384 \mathrm{~g}$ and $402 \mathrm{~g}$ at 6 months following the exposure to sarin or the pure air and $466 \mathrm{~g}$ and $480 \mathrm{~g}$ at 12 months following the exposure to sarin or the pure air. On the other hand, the decrease in the liver weight at 3 months following the exposure to sarin at level 1 , at 6 months following the exposure to sarin at level 1 and 2(S) and at 12 months following the exposure to sarin at level 1 and $2(R)(p<0.05)$ was observed. Nevertheless, no relationship between the decrease in the liver weight and the changes in the scheduled DNA synthesis, the concentration of liver DNA and liver total protein was evaluated.

\section{Discussion}

Clinical manifestation of exposure to OPs are extremely diverse primarily resulting from the inhibition of AChE activity, including several types of genotoxic effects, teratogenic effects and immunossuppresion $(13,18)$. The ability of OP agents to induce changes in nucleic acid and protein metabolism was primarily demonstrated in animals or humans exposed to organophosphorus pesticides $(5,20)$, nevertheless, there are some published results demonstrating the ability of highly toxic OPs (nerve agents) to signi- ficantly influence the metabolism of nucleic acids and proteins following the exposure to high as well as low doses of nerve agents such as soman $(6,15,17)$. Moreover, the genetic effects of sarin at symptomatic doses were monitored in people poisoned during the Tokio sarin disaster (10).

Our results confirm that not only clinically manifested but also asymptomatic doses of nerve agent sarin are able to alter the metabolism of DNA as well as total protein in liver of sarin exposed rats. This alteration changes in time. At first, the significant decrease in the synthesis of DNA de novo occured. This alteration was detectable even at three months following the exposure. The changes in concentration of liver DNA and total protein started later and they were detectable mainly at six months, partly at twelve months following the exposure. It means that the changes in DNA and total protein concentrations arise as a result of changes in synthesis of DNA in earlier time period following the exposure.

Thus, nerve agents such as sarin are able to alter the metabolism of DNA and subsequently proteins in exposed rats at low, asymptomatic doses for a long time. Although these findings are difficult to extrapolate directly to human low-level exposure to nerve agents, they indicate that subtle alteration of nucleic acid and protein metabolism can also occur in humans at exposures which do not cause any clinical signs or symptoms.

\section{Acknowledgements}

The authors thank to Mrs. L. Kriesfalusyová, Mrs. E. Vodáková and Mrs. J. Petrová for their skilful technical assistance. This study was supported by the grant of Ministry of Defense, No 66020397202.

\section{References}

1. Bajgar J. Biological monitoring of exposure to nerve agents. $\mathrm{Br} \mathrm{J}$ Ind Med 1992;49:648-53.

2. Burton K. Study of conditions and mechanism of the diphenylamine reaction for the colorimetric estimation of deoxyribonucleic acid. Biochem J 1955;62:315-23.

3. Chmelař V, Vodička I. The influence of cystamine on the incorporation of thymidine into marrow cells. Suppl Sbor věd Prací LFUK HK 1985;28:495-503 (in Czech).

4. Chromý V, Vozníček J. Total protein (BIO-LA-TEST). Brno:Lachema, 1976; p. 31 (in Czech).

5. Das P, John G. Induction of sister chromatid exchanges and chromosome aberrations in vivo in Etroplus suratensis (Bloch) following exposure to organophosphorus pesticides. Toxicol Lett 1999;104:111-6.

6. Doebler JA, Moore RA, Wall TJ, Anthony A. Brain neuronal RNA metabolism during sustained low-level soman toxication. Life Sci 1984;34:659-67.

7. Haley RW, Kurt TL, Hom J. Is there a Gulf War syndrome? - searching for syndromes by factor analysis of symptoms. JAMA 1997;277:215-22.

8. Klein AK. The effects of in vitro exposure to the neurotoxins sarin (GB) and soman (GD) on unscheduled DNA synthesis by rat hepatocytes. Toxicol Lett 1987:38:239-47.

9. Landrigan PJ. Illness in Gulf War veterans. JAMA 1997;277:259-61.

10. Li Q, Minami M, Clement JG, Boulet CA. Elevated frequency of sister chromatide exchanges in lymphocytes of victims of the Tokio sarin disaster and in experiments exposing lymphocytes to by-products of sarin synthesis. Toxicol Lett 1998;98:95-103.

11. Lowry OH, Rosebrough NJ, Farr AL, Randall R. Protein measurements with the Folin phenol reagent. J. Biol Chem 1951;193:165-75.

12. Marrs TC. Organophosphorus poisoning. Pharmacol Ther 1993;58:51-66. 
13. Midtling JE, Barnett PG, Coye MJ. Clinical management of organophosphorus poisoning. West J Med 1985;142:514-8.

14. Ohtomi S, Takase M, Kumagai F. Sarin poisoning in Japan. A clinical experience in Japan Self Defense Force (JSDF) Central Hospital. Int Rev Arm For Med Ser 1996;69:97-102.

15. Sevaljevic L, Boskovic B, Glibetic M, Tomic M. Effect of soman on the organization of rat brain ribosomes and the translational activity of mRNA in a cell-free system. Arch Toxicol 1989;63:244-7.

16. Sierra-Torres CH, Cajas-Salazar A, Hoyos LS, Zuleta M, Whorton EB, Au WW. In vitro and in vivo genotoxic activity of miral, an organophosphorus insecticide used in Colombia. Mutation Res 1998;415:59-67.

17. Skopec F, Bajgar J. Liver and brain DNA contents in acute soman intoxication. Sbor věd Prací LFUK HK 1992;35:253-62.

18. Sullivan JB. Immunological alterations and chemical exposure. Clin Toxico 1989;27:311-43.

19. Wilson BW, Kawakami TG, Cone $\mathrm{N}$ et al. Genotoxicity of the phosphoramidate agent tabun (GA). Toxicology 1994;86:1-12.

20. Woo Y, Lai DY, Argus MF, Arcos JC. Carcinogenicity of organophosphorus pesticides/compounds: an analysis of their structure-activity relationship. Environ Carcino Ecotox Revs 1996;C14:1-42.

21. Taylor P. Anticholinesterase agents. In: Hardman JG, Limbird LE (eds): The Pharmacological Basis of Therapeutics, $9^{\text {th }}$ ed. New York, McGraw Hill 1996; pp. 161-176.

Submitted November 1999.

Accepted March 2000.

Doc. MUDr. Jiř́ Kassa, CSc., Purkyně Military Medical Academy,

Department of Toxicology, 50001 Hradec Králové, Czech Republic. e-mail: kassa@pmfhk.cz 